\title{
Wyrok Sądu Metropolitalnego w Katowicach (c. Sobański) z 20.11.1997 r. z tytułu braku konsensu spowodowanego chorobą psychiczną
}

Ius Matrimoniale 4 (10), 249-255

1999

Artykuł został zdigitalizowany i opracowany do udostępnienia w internecie przez Muzeum Historii Polski w ramach prac podejmowanych na rzecz zapewnienia otwartego, powszechnego i trwałego dostępu do polskiego dorobku naukowego i kulturalnego. Artykuł jest umieszczony w kolekcji cyfrowej bazhum.muzhp.pl, gromadzącej zawartość polskich czasopism humanistycznych i społecznych.

Tekst jest udostępniony do wykorzystania w ramach dozwolonego użytku. 


\section{Wyrok Sądu Metropolitalnego w Katowicach (c.Sobański) z 20.11.1997r. z tytulu braku konsensu spowodowanego chorobą psychiczną.}

\section{PRZEBIEG SPRAWY:}

AK oraz BP, zawarli małżeństwo $20.8 .1988 \mathrm{w}$ kościele parafialnym w (...). Ważność tego małżeństwa zaskarżył AK 21.8.1990 w Sądzie Kościelnym w (...). Sąd ten orzekł 28.9.1993, iż nie udowodniono nieważności małżeństwa. Wskutek apelacji powoda sprawa znalazła się w drugiej instancji, tj. w Sądzie Metropolitalnym w (...), który 28.10.1996 orzekł, iż udowodniono nieważność małżeństwa z tytułu niezdolności pozwanej do podjęcia istotnych obowiązków małżeńskich (k.1095 n.3). Uwzględniając prośbę powoda Najwyższy Trybunał Sygnatury Apostolskiej dekretem z 16.6.1997 wyznaczył Sąd Metropolitalny w Katowicach do rozpatrzenia sprawy w trzeciej instancji. Wobec braku dalszych wniosków dowodowych Sąd uznał materiał dowodowy za wystarczający i orzekł jak następuje:

\section{PRAWNY I FAKTYCZNY STAN SPRAWY:}

I. Powód wniósł o orzeczenie nieważności małżeństwa ,z powodu choroby psychicznej pozwanej lub jej niezdolności do przyjęcia i wypełnienia istotnych obowiązków małżeńskich $\mathrm{z}$ racji poważnych zaburzeń psychicznych. Sąd I instancji prowadził sprawę, ,z tytułu braku wystarczającego używania rozumu (k.1095 n.l) (!)" i orzekł, iż ,nie udowodniono niezdolności kobiety do małżeństwa $z$ powodu jej choroby psychicznej". Wynika z tego, a także z przytoczonych motywów prawnych, że Trybunał I instancji miał na oku wyłącznie k.1095 n. l. Trybunał II instancji zwrócił się do stron z zapytaniem ujętym następująco: „czy Pan(i) prosi o rozpatrzenie swej sprawy w II instancji i czy podtrzymuje tytuł niezdolności podjęcia i wypełnienia obowiązków małżeńskich 
(kan.1095 $\$ 1 \mathrm{KPK}$ ) z powodu choroby psychicznej po stronie pozwanej - niewiasty?". Przytaczając werbalnie normę k.1095 n.3 Trybunał wskazał na k.1095 n.l, a następnie podał, że wspomniana niezdolność ma być spowodowana chorobą psychiczną. Powód w swej odpowiedzi usiłuje doprecyzować tytuły nieważności: podtrzymuje tytuł z I instancji, a ,także tytuł niezdolności do podjęcia i wypełnienia obowiązków małżeńskich", a to ,z powodu choroby psychicznej”. Przewodniczący Trybunału II instancji dekretem z 30.11.1995 ustalił przedmiot sporu: „czy nieważne jest małżeństwo stron $z$ tytułu niezdolności niewiasty do podjęcia istotnych obowiązków małżeńskich". $Z$ tego też tytułu Trybunał II instancji orzekł nieważność małżeństwa $z$ wyraźnym odniesieniem się do k.1095 n.3. Trybunał stwierdzil, że tym samym uchyla wyrok I instancji, a pominął milczeniem fakt, że Trybunał I instancji orzekł z k.1095 n.1. Z kolei w motywach prawnych Trybunał II instancji przywołal k.1095 n. 2 i 3 .

Sprawa wymaga przeto ustalenia jej podstaw prawnych, gdyż k.1095 n.l oraz k. 1095 n.3 dysponują odrębne tytuły nieważności. Już pierwsze zaznajomienie się sprawa, czyli ze skarga powoda, nasuwa przypuszczenie, że w grę mogą wchodzić obydwa tytuły nieważności, natomiast nagromadzony materiał dowodowy winien dać orientację, z którego tytułu należy orzekać. Trzeba przeto zacząć od zestawienia i oceny nagromadzonych dowodów.

\section{Material dowodowy.}

\section{A. Dokumentacja:}

W aktach sprawy znajdują się:

1) Zaświadczenie Zespołu Psychiatrycznej Opieki Zdrowotnej w (...) z 18.8.1990, wedle którego pozwana leczyła się tam od 9.9. do 14.12.1989.

2) Wyciag $z$ historii choroby tegoż leczenia $z$ diagnozą ,przewlekły zespół schizofrenopodobny z odczynem depresyjnym".

3) Postanowienie Prokuratury Rejonowej w (...) z 27.11.1989 umarzające śledztwo przeciw pozwanej z powodu utopienia 7-miesięcznej córki. Umorzenie uzasadniono niepoczytalnością pozwanej: „Z wydanej przez biegłą lekarzy psychiatrów na podstawie przeprowadzonej obserwacji sądowo-psychiatrycznej opinii wynika, że podejrzana BK cierpi 
na chorobę psychiczną w postaci przewlekłego zespołu schizofrenopodobnego $z$ odczynem depresyjnym.

4) Odpis historii choroby oddziału wewnętrznego ZOS w (...), gdzie pozwana leczyła się od 6.2. do 9.2.1989 z rozpoznaniem ,zatrucie lekami w celach samobójczych". Konsultowany lekarz psychiatra uznał za konieczną konsultację psychologiczną. Testem Rorschacha stwierdzono: „Produktywność wyobrażeniowa dość uboga, nieco dziwaczna, przemawiająca za zaburzeniami w sferze myślenia i sferze emocjonalno-uczuciowej. Wskazane dalsze leczenie psychiatryczne". Pozwaną wypisano z zaleceniem ,pilnej opieki rodzinnej" oraz kontroli w PZP.

\section{B. Opinie bieglych.}

1) Trybunał I instancji zwrócił się do biegłego o opinie, czy pozwana zawierając małżeństwo „była chora psychicznie, a jeżeli tak, to jaka to była choroba i w jaki sposób wpłynęła na wypełnianie obowiązków małżeńskich". Biegły, stwierdziwszy że - oprócz teściowej i bratowej pozwanej - „wszystkie pozostałe zeznania zgodnie podaja że pozwana

przed ślubem była osobą zdrową psychicznie, a dopiero po porodzie wystąpiła u niej psychoza", zaopiniował, że pozwana w czasie zawierania małżeństwa ,nie zdradzała objawów choroby psychicznej, niedorozwoju umysłowego ani innych zakłóceń funkcji psychicznych mając zachowaną zdolność do podjęcia i wypełnienia istotnych obowiązków małżeńskich". Biegły nie poddał analizie dokumentacji szpitalnej.

2) Pytanie, jakie Trybunał II instancji postawił wyznaczonej przez siebie biegłej, brzmi: „czy pozwana w czasie zawierania małżeństwa była chora psychicznie (w formie ukrytej)? „Biegła poddała analizie dokumentację lekarską i stwierdziła: „Dane zawarte w aktach sprawy pozwalają na stwierdzenie $z$ całą pewnością; faktu, że pozwana cierpiała na chorobę psychiczna, w której dominującym objawem były zaburzenia afektywne (zespół depresyjny, głęboki, z cechami tzw. melancholii, $z$ okresowo dołączającymi się objawami psychotycznymi). $Z$ danych uzyskanych z wywiadu od powoda, oraz ojca pozwanej wynika, że zaburzenia te miały charakter nawrotowy. Po okresie poprawy, jaką obserwowano po kilku miesiącach od porodu, w lecie 1989 r. nastąpil nawrót objawów depresyjnych z dużym nasileniem myśli samobójczych - we wrześniu 1989 r. Zarówno obraz kliniczny zaburzeń, jak i fakt nawrotowości, przemawiają za istnieniem u pozwanej BP choroby afektywnej 
(dawniej określanej mianem psychozy maniakalno-depresyjnej), która należy do grupy tzw. chorób endogennych, dla podkreślenia czynnika genetycznego $\mathrm{w}$ ich etiologii, znaczenia dziedziczności, jako bardzo ważnego elementu. Czynniki dodatkowe (w tym między innymi poród) często odgrywają rolę ,wyzwalających" tkwiącą u podłoża predyspozycję do zachorowania. Przebieg choroby cechuje się nawrotowością, z okresami remisji (często bardzo dobrej), niekiedy choroba ma charakter naprzemiennie występujących stanów depresyjnych, oraz stanów po podwyższonego nastroju i napędu".

Biegła przyznaje, że „o ile nie ma waţpliwości co do istnienia wyraźnej choroby psychicznej u pozwanej po zawarciu małżenstwa”, to ,trudniejsze jest określenie stanu zdrowia psychicznego pozwanej w okresie przed ślubem stron". Biegła analizuje w tym aspekcie materiał dowodowy i wysuwa konkluzje bardzo ostrożne: całokształt danych ,jeśli nawet zawiera pewne mankamenty, które nie pozwalają na stwierdzenie wysokiej pewności istnienia wyraźnych zaburzeń psychicznych u pozwanej przed czy w okresie zawierania małżeństwa z powodem, absolutnie nie wyklucza ich istnienia w tym przedślubnym okresie".

Nie można więc - jak to napisano w wyroku II instancji - utrzymywać, iż ,biegły ekspert powołany w II instancji stwierdził, że pozwana w chwili zawierania malżeństwa podlegała chorobie afektywnej endogennej”. Biegła nie twierdzi, że pozwana wówczas „podlegała chorobie", a jedynie nie wyklucza choroby. Takie „niewykluczenie” nie wystarcza do orzeczenia nieważności małżeństwa, chorobę wzgl. jako przyczynę niezdolności trzeba udowodnić.

\section{Zeznania.}

Oprócz faktów udokumentowanych medycznie (p.p.A) bezsporny jest tylko fakt choroby psychicznej siostry babci pozwanej i jej syna (przyznaje to pozwana, mówią o tym świadkowie). Powód wyznał biegłej, że sąsiadka po ślubie informowała go o leczeniu się pozwanej przed ślubem i zatajeniu tego przed nim, ale brak na to jakichkolwiek dowodów, nie wspomina o tym nikt spośród świadków, pozwana i jej ojciec zdecydowanie zaprzeczaja, a Naczelny Lekarz ZOS w (...) poinformowal, że pozwana nie leczyła się tam w r.1987. Nie widać przeto podstaw faktycznych dla ustalenia dokonanego przez Trybunal II instancji, jakoby „pozwana przed ślubem ukryła chorobę”. W wywiadzie z 9.9.1989 stwier- 
dzono wyraźnie: „dotychczas nie leczona psychiatrycznie”. Zeznania matki powoda (,wiem od ludzi o jej nienormalnym zachowaniu, np. w szkole podstawowej darła zeszyty dzieciom") są odosobnione.

Świadek ZK scharakteryzował pozwaną jako ,mruk", ojciec pozwanej mówi, że lubiła życie samotne, „lubiła samotność, choć była wesoła" - zeznaje jej krewna JM.

Trzeba też odnotować sprzeczność w wypowiedziach pozwanej. W piśmie z 22.10.1990 do Trybunału I Instancji pisze, że małżeństwo było nie udane od samego dnia ślubu", a zeznając twierdzi, że ,zgodne i szczęśliwe małżeństwo trwało do 10 listopada 1988". Zeznania powoda harmonizują $z$ drugą wypowiedzią pozwanej.

\section{Ocena materialu dowodowego.}

Bezsporne jest, że 6.2.1989 uznano konieczność psychiatrycznego leczenia pozwanej, oraz że 9.9.1989 zdiagnozowano ,przewlekły zespół schizofrenopodobny". Konieczność leczenia stwierdzono w dwa tygodnie po urodzeniu dziecka (ur. 24.1.1989), a więc w niespełna pół roku po zawarciu małżeństwa. Biegła II instancji podaje, że choroba wówczas rozpoznana należy do chorób endogennych, a więc uwarunkowanych dziedzicznie, a ,wyzwalanych" czynnikami dodatkowymi (np. poród). Choroba ta cechuje się nawrotowościa, co właśnie miało miejsce u pozwanej. Dochodząc kwestii, czy choroba drążyła pozwaną w sposób latentny już w chwili zawierania małżeństwa, trzeba zwrócić uwage na zachorowania $\mathrm{w}$ rodzinie, a także na fakt zażycia 6.2.1989 40 tabletek dwóch leków psychotropowych. Znaczy to, że pozwana wtedy już taki lek posiadała, a to każe początki choroby przesunąć przed 6.2.1989.

Świadkowie są nader lakoniczni, ale krytyczne przefiltrowanie zeznań pozwala na uchwycenie pewnych faktów, a to: inklinacje pozwanej ku samotności (ojciec i bracia pozwanej), obojętność pozwanej wobec powoda (przyznana przez nią samą) - i wreszcie zeznanie pozwanej: „od chwili porodu coś się ze mną złego stało”. To właśnie potwierdza, że poród był czynnikiem nie powodującym, lecz wyzwalającym chorobe.

Tak widziany i oceniony obraz sprawy prowadzi Sąd do wniosku, iż pozwana zawierała małżeństwo w trakcie drążącej ją już, aczkolwiek wówczas słabo jeszcze podpadającej choroby psychicznej. 


\section{Prawne podstawy orzeczenia.}

Stwierdzenie, że pozwana zawierając małżeństwo podlegała już chorobie psychicznej, każe jako podstawę orzeczenia przyjąć k.1095 n.l: drążąca pozwaną choroba zakłóciła funkcjonowanie jej władz duchowych, poznawczych i wolitywnych. Zakłócenie takie wtedy powoduje nieważność małżeństwa, gdy wywołuje skutek określony w k.1095 n. l, mianowicie brak wystarczającego używania rozumu. Pojęcie wystarczającego używania rozumu jest ogólne, obejmuje wszystkie sytuacje, w których czynniki wrodzone czy nabyte ograniczają możliwości poznania i swobodnego podejmowania decyzji. Wśród tych czynników znajdują się perturbacje natury schizofrenicznej, występujące w różnych postaciach i kombinacjach, a powodujące dysocjację myśli, zaburzające kontakt duchowy między daną osobą a światem i wypaczające rozeznanie, a konsekwentnie wolność i autentyzm podejmowanych decyzji.

W orzecznictwie kościelnym zwraca się uwagę, że wspomniane perturbacje moga oddziaływać na władze duchowe człowieka już w tzw. fazie przedpsychotycznej. Szczególnie wtedy, gdy wyraźne objawy choroby stopniowo i ewolucyjnie narastają, trzeba wnosić, że proces chorobowy toczył sie już przed jego ujawnieniem. Jako jego wyraz uznaje wtedy pewne cechy uchodzace za charakterologiczne, który jednak w takich przypadkach, w świetle późniejszej eksplozji choroby, trzeba retrospektywnie postrzegać jako jej już symptomy (RRT Dec..., 85,1996,193-197).

Referowany i oceniony wyżej materiał dowodowy prowadzi przeto do wniosku, że małżeństwo stron jest nieważne z przyczyn, o których w k. 1095 n. 1 .

\section{Orzeczenie.}

Dokonane wyżej ustalenie oznacza, że Sąd zatwierdza wyrok Trybunału II instancji, mimo że ten orzekł nieważność małżeństwa na podstawie k.1095 n.3. Od samych początków jednak sprawa toczyła się o nieważność małżeństwa ,z powodu choroby psychicznej” pozwanej. Istnienie tej choroby psychicznej zostało udowodnione i ona stanowi fakt prawny uzasadniający orzeczenie nieważności małżeństwa. Orzekając nieważność małżeństwa Sąd opiera się na tych samych dowodach i argumentach jak Trybunał II instancji. Wyroki różnią się wprawdzie co do 
wskazanej normy prawnej, odwołują się jednak do tych samych faktów i dowodów. Dodać trzeba, że tytuł nieważności z k.1095 n.1 wchłania tytuł, o którym w k.1095 n.3 (ale nie odwrotnie). Wyrok niniejszy jest przeto niewatpliwie zgody $z$ wyrokiem II instancji.

Tak więc Sąd Metropolitalny stwierdza i orzeka, iż udowodniono nieważność małżeństwa i tym samym zatwierdza wyrok II instancji. 